\title{
Analisis Post to Followers Ratio Instagram Pada 10 Daftar Wanita Tercantik Di Asia
}

\author{
David Agung Akoso K. Hedo \\ STMIK STIKOM INDONESIA \\ davidhedo1998@gmail.com
}

\begin{abstract}
Instagram is a mobile based on iOS, Android and Windows Phone where users can shoot, edit and post photos or videos to the main page of Instagram and other social networks. Photos or videos that are shared will later be displayed in the feeds of other users who are your followers. The friendship system on Instagram uses the terms following and followers. Following means you are following users, while follower means other users who are following you. Furthermore, each user can interact by commenting and responding to likes on the shared photos. The increasing number of Instagram users can certainly provide opportunities for celebrities or artists to make the Instagram platform a social media platform. The Instagram accounts of the 10 Most Beautiful Women in Asia are: yaelshelbia, lalalalisa_m, queentzuyu, ivaanalawi, bingbing_fan, aishwaryaraibachchan_arb, julianaevans, natashawilona12, rern_nat, diemmyvu. The purpose of this study is to calculate the credibility of the performance of Instagram accounts on the 10 Most Beautiful Women List in Asia. The method used for this research is quantitative exploratory method. The results of this study indicate that the bingbing_fan Instagram account gets the first rank and has good account performance credibility.
\end{abstract}

\begin{abstract}
ABSTRAK
Instagram merupakan mobile berbasis iOS, Android dan Windows Phone dimana pengguna dapat membidik, mengedit dan mem-posting foto atau video ke halaman utama Instagram dan jejaring sosial lainnya. Foto atau video yang dibagikan nantinya akan terpampang di feed pengguna lain yang menjadi follower Anda. Sistem pertemanan di Instagram menggunakan istilah following dan follower. Following berarti Anda mengikuti pengguna, sedangkan follower berarti pengguna lain yang mengikuti Anda. Selanjutnya setiap pengguna dapat berinteraksi dengan cara memberikan komentar dan memberikan respon suka terhadap foto yang dibagikan. Maraknya jumlah pengguna Instagram tentu dapat memberikan peluang bagi selebritis atau artis untuk menjadikan platform Instagram sebagai platform social media. Adapun akun Instagram dari 10 Daftar Wanita Tercantik Di Asia yaitu : yaelshelbia, lalalalisa_m, queentzuyu, ivaanalawi, bingbing_fan, aishwaryaraibachchan_arb, julianaevans, natashawilona12, rern_nat, diemmyvu. Tujuan dari penelitian ini yaitu untuk menghitung kredibilitas dari performa akun Instagram pada 10 Daftar Wanita Tercantik Di Asia. Metode yang digunakan untuk penelitian ini yaitu metode eksploratif kuantitatif. Hasil dari penelitian ini menunjukan bahwa akun Instagram bingbing_fan mendapatkan peringkat pertama dan memiliki kredibilitas performa akun yang baik.
\end{abstract}

Keyword : Credibility Account Instagram ; Social Media Instagram ; Post to Followers Ratio; 10 Daftar Wanita Tercantik Di Asia 


\section{PENDAHULUAN}

Teknologi informasi dan komunikasi yang telah berkembang pesat mampu menghantarkan manusia untuk menciptakan bentuk baru cara berkomunikasi dan berinteraksi melalui media sosial. Sarana berkomunikasi menggunakan media sosial sangat berperan dalam aktifitas keseharian bersosial di masyarakat. Teknologi informasi dan komunikasi dirasa penting keberadaannya oleh penggunanya, dimana salah satu tujuannya adalah untuk bertukar infomasi. Keberadaan sarana komunikasi ini memberikan dampak yang signifikan di berbagai bidang seperti, sosial, ekonomi, Pendidikan dan bidang lainnya. Komunikasi tidak hanya dapat di lakukan secara fisik, tetapi juga dapat di lakukan dengan menggunakan berbagai media sosial di dunia maya. Keunggulan layanan media sosial adalah memberikan ruang komunikasi dua arah antara konsumen-perusahaan dan konsumen-konsumen. Komunikasi dua arah ini memampukan konsumen untuk berpartispasi, kolaborasi dan berinteraksi, yang pada intinya konsumen tidak lagi objek tetapi subyek pemasaran. Dengan pesatnya perkembangan teknologi media sosial, telah memberikan dampak terhadap situs - situs komunikasi, dari yang awalnya hanya sekedar email, dan chatting, sekarang sudah banyak jejaringan media sosial yang bisa digunakan sebagai alat komunikasi. Contohnya seperti, facebook, Instagram, twitter, Telegram, Snapchat. Media sosial yang sangat diminati salah satunya adalah instagram. Instagram memiliki lebih dari 1 miliyar pengguna aktif [1]. Instagram adalah media sosial yang digunakan sebagai tempat menyebarkan dan berbagai informasi, berinteraksi dengan orang banyak, serta dapat mengenal lebih dekat dengan sesama pengguna .Instagram merupakan aplikasi berbagi foto yang memungkinkan pengguna mengambil foto, menerapkan filter digital, dan membagikannya ke berbagai layanan jejaring sosial [2]. Maraknya penggunaan Instagram membuat para peneliti ingin melakukan penilaian secara kualitatif terhadap akun - akun yang ada pada media sosial Instagram. Beberapa para peneliti telah melakukan penelitian yang terkait dengan penggunaan media sosial Instagram. Contohnya seperti penelitian Instagram sebagai media online shop dan juga sebagai media memamerkan gaya hidup atau kegiatan sehari-hari dari pemilik akun. Dalam hal ini peranan sistem informasi dalam Instagram adalah sebagai prediksi [3], [4], pendukung keputusan [5], dan keamanan [6]. Namun diantara beberapa penelitian yang sudah ada mengenai Instagram, belum ada peneliti yang meneliti tentang pencarian rasio - rasio yang dapat digunakan sebagai alat ukur dalam menilai berbagai aspek pada Instagram. Rasio - rasio ini yang nantinya dapat digunakan untuk melakukan analisa atau penelitian kuantitatif. Beberapa aspek yang dapat dinilai menggunakan rasio - rasio hasil dari penelitian tersebut yaitu, yang pertama ingetsmen yang ada pada akun Instagram tersebut, apakah ingetsmen dari akun tersebut sudah bagus atau belum. Kedua, rasio - rasio ini juga bisa digunakan untuk mengukur kredibilitas dari akun Instagram tersebut. Dan yang ketiga, untuk menilai performa dari konten atau post yang posting pada akun Instagram tersebut. (Hendika Permana 2021)

\section{TINJAUAN PUSTAKA}

Instagram merupakan salah satu medium yang memiliki peran penting terhadap terhadap kebiasaan baru mengakses berita atau informasi.(J Muntu, Pingkan Tangkudung, and H Lotulung 2021)

Instagram merupakan salah satumediasosialyang memiliki pengaruh besar dan penting dalam suatu bisnis. Sampai saat ini, Instagram sudah memiliki 700 juta pengguna dan setiap harinya sekitar 60 juta foto dibagikan dan dapat memberikan 1,6 milyar likes. Instagram merupakan aplikasi yang paling popular yang bergunauntukmembagikanfoto dan video.(Untari and Fajariana 2018) 
Instagram secara sederhana dapat didefinisikan sebagai aplikasi mobile berbasis iOS, Android dan Windows Phone dimana pengguna dapat membidik, meng-edit dan mem-posting foto atau video ke halaman utama Instagram dan jejaring sosial lainnya. Foto atau video yang dibagikan nantinya akan terpampang di feed pengguna lain yang menjadi follower Anda. Sistem pertemanan di Instagram menggunakan istilah following dan follower. Following berarti Anda mengikuti pengguna, sedangkan follower berarti pengguna lain yang mengikuti Anda. Selanjutnya setiap pengguna dapat berinteraksi dengan cara memberikan komentar dan memberikan respon suka terhadap foto yang dibagikan. Instagram awalnya dikembangkan oleh startup bernama Burbn, Inc yang dimotori oleh Kevin Systrom dan Mike Krieger. Di tangan keduanya Instagram sukses membuat raksasa jejaring sosial Facebook bertekuk lutut sehingga bersedia membelinya seharga $\$ 1$ miliar, akuisisi itu terjadi pada 9 April 2012.(Winarso 2015)

Instagram adalah aplikasi media sosial berbasis Android untuk smartphone, iOS untuk iPhone, Blackberry, Windows Phone dan sekarang juga dapat dijalankan di komputer atau PC Anda. Namun, ketika digunakan pada komputer, ini tidak sepenuhnya identik dengan ponsel(Asfihan 2021)

Secara istilah Instagram diambil dari kata "Insta" yang berasal dari kata "Instan". Nama ini diambil dari kamera polaroid dimana merupakan kamera instan yang langsung jadi seketika. Sedangkan kata "gram" diambil dari kata "Telegram" yang mampu mengirim informasi secara cepat. Dalam hal ini, kata kata yang dibuat sesuai dengan tujuan Instagram yang mampu mengirim foto dan video dalam jaringan internet secara instan dan cepat. Selain disebut Instagram, orang masa kini lebih suka menyebutnya IG atau Insta. Dari definisi singkat tersebut, secara umum Instagram dapat diartikan sebagai aplikasi yang dapat difungsikan sebagai media berbagi foto dan video dalam sebuah jejaring sosial, memungkinkan pengguna untuk mengambil foto dan video, dan menambahkan filter untuk menambah kesan menarik pada foto. Utamanya, Instagram lebih difokuskan pada perangkat smartphone seperti Android dan iOS. Namun pengguna tetap dalam menjalankan Instagram dalam mode web app meskipun dengan fitur terbatas. Sama seperti jejaring media sosial lainnya, Instagram memiliki konsep interaksi antar pengguna dengan mengikuti (following) atau pengikut (follower). Pengguna juga dapat menambahkan komentar pada foto maupun video, menyukai, mengirim, hingga menyimpannya dalam sebuah akun.(dianisa 2020)

Instagram adalah sebuah aplikasi dari Smartphone yang khusus untuk media sosial yang merupakan salah satu dari media digital yang mempunyai fungsi hampir sama dengan twitter, namun perbedaannya terletak pada pengambilan foto dalam bentuk atau tempat untuk berbagi informasi terhadap penggunanya. Instagram juga dapat memberikan inspirasi bagi penggunanya dan juga dapat meningkatkan kreatifitas, karena Instagram mempunyai fitur yang dapat membuat foto menjadi lebih indah, lebih artistik dan menjadi lebih bagus.(ANWAR SIDIQ 2017)

\section{METODE PENELITIAN}

Penelitian ini menggunakan metode eksploratif kuantitatif untuk mengetahui kredibilitas dari performa akun Instagram Pada 10 Daftar Wanita Tercantik Di Asia. Metode eksploratif merupakan metode yang digunakan untuk merumuskan masalah secara lebih terperinci.(Hendika Permana 2021)

Tujuan dari penelitian ini yaitu untuk mengetahui nilai kredibillitas dari performa akun Instagram Pada 10 Daftar Wanita Tercantik Di Asia. Ada beberapa langkah yang harus dilakukan dalam penelitian 
ini, sehingga mampu menemukan peringkat pertama akun Instagram Pada 10 Daftar Wanita Tercantik Di Asia yang memiliki performa terbaik. Langkah-langkah yang dilakukan pada penelitian ini yaitu :

\section{a. Melakukan Eksplorasi Pada Website Untuk Menentukan Objek yang Akan Dianalisa.}

Eksplorasi ini dilakukan pada beberapa halaman website yang menyediakan informasi mengenai objek yang akan di teliti. Setelah ekslorasi selesai dilakukan, sehingga ditemukan nama-nama wanita tercantik di Asia yang akan dijadikan objek analisa. Setelah melakukan eksplorasi pada halaman website, maka langkah selanjutnya yaitu mencari nama akun Instagram dari masing-masing wanita tercantik di Asia tersebut. Pastikan semua wanita tercantik di Asia tersebut memiliki akun pada aplikasi sosial media Instagram.

\section{b. Menghitung Nilai Rata-Rata Variable Dari 10 Daftar Wanita Tercantik Di Asia.}

Pada langkah ini, peneliti menghitung nilai variable post dan variable followers. Variabel merupakan suatu besaran yang dapat diubah atau berubah sehingga dapat mempengaruhi peristiwa atau hasil penelitian(Dosen Pendidikan 2 2021). Untuk menghitung nilai rata-rata dari variable post dan variable followers yaitu dengan cara mengambil minimal 10 postingan kemudian di hitung sehingga menemukan nilai rata-rata dari masing-masing variabel.

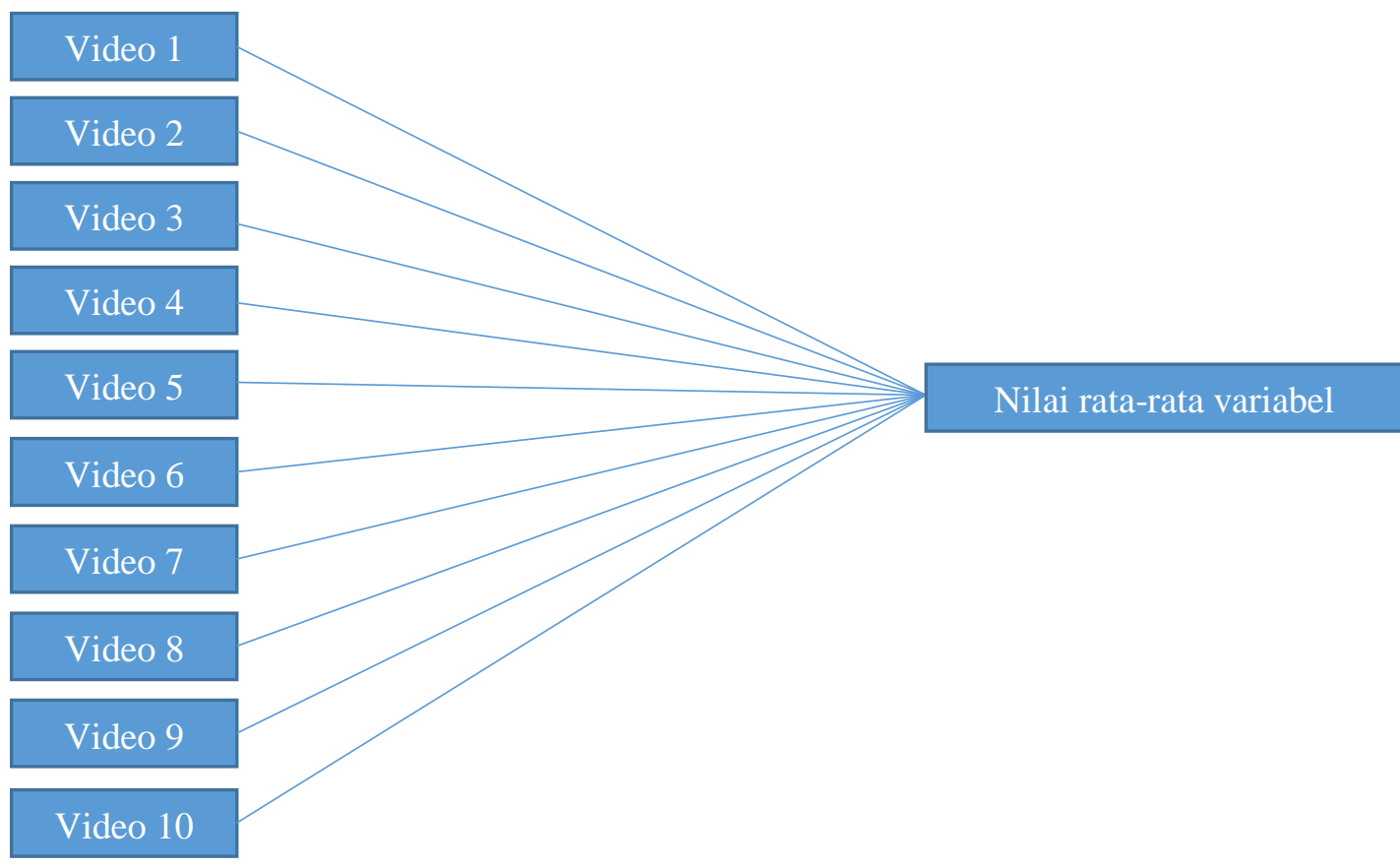

Gambar 1. Analisa nilai rata-rata variable

\section{c. Menghitung Nilai Kredibilitas Rasio}

Untuk menghitung nilai kredibilitas dari post to followers ratio, peneliti menggunakan cara membagi nilai variabel pertama dengan nilai variabel kedua. Jika video comments memiliki nilai 100 dan video views memiliki nilai 300, maka cara menghitungnya yaitu $100: 300=0,3$. Dengan begitu nilai dari video comments to video views ratio adalah 0,3 . 


\section{d. Menentukan Peringkat Pada Akun Instagram}

Pada langkah terakhir yang dilakukan pada penelitian ini yaitu menentukan peringkat pada masing-masing rasio yang ada. Pada penentuan peringkat perlu melihat karakteristik dari rasio yang di teliti. Jika karakteristik rasio merupakan rendah, maka objek yang memiliki nilai terendah akan mendapatkan angka 5 dan objek yang memiliki nilai tertinggi akan mendapatkan angka 1. Namun jika rasio memiliki karakteritik tinggi maka objek yang mendapatkan nilai tinggi akan mendapatkan angka 5 dan objek yang mendapatkan nilai terendah akan mendapatkan angka 1. Setelah mendapatkan hasil kredibilitas ratio maka dapat disimpulkan objek yang mana mendapatkan peringkat 1 sampai dengan peringkat 5 .

\section{HASIL DAN PEMBAHASAN}

\section{Akun Instagram dari 10 Daftar Wanita Tercantik Di Asia 2021, diantaranya :}

\section{a. yaelshelbia}
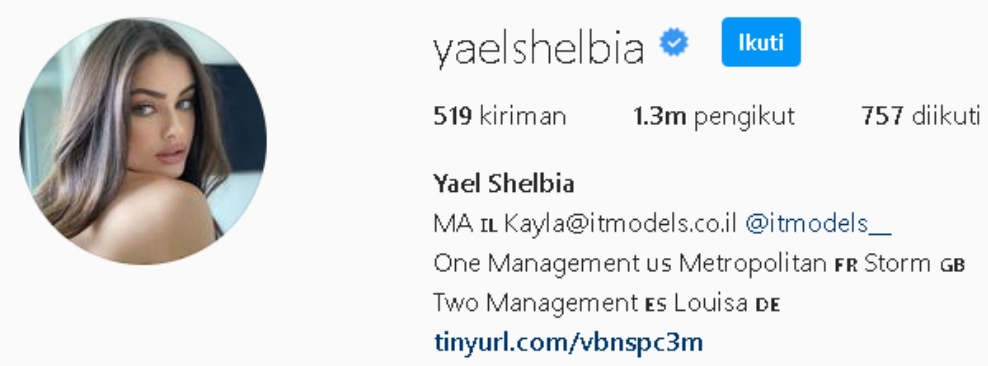

Gambar 1. Akun Instagram yaelshelbia

Sumber : https://www.instagram.com/yaelshelbia/ (akses pada 20-10-2021)

\section{b. lalalalisa_m}
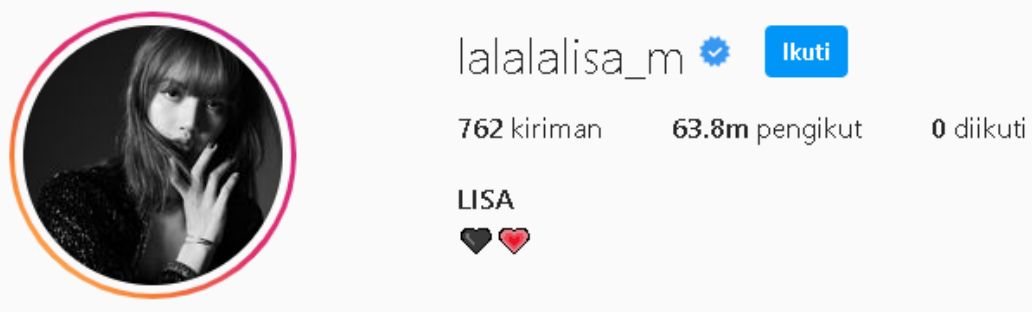

LISA

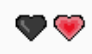

Gambar 2. Akun Instagram lalalalisa_m

Sumber : https://www.instagram.com/lalalalisa_m/?hl=id (akses pada 20-10-2021) 


\section{c. queentzuyu}
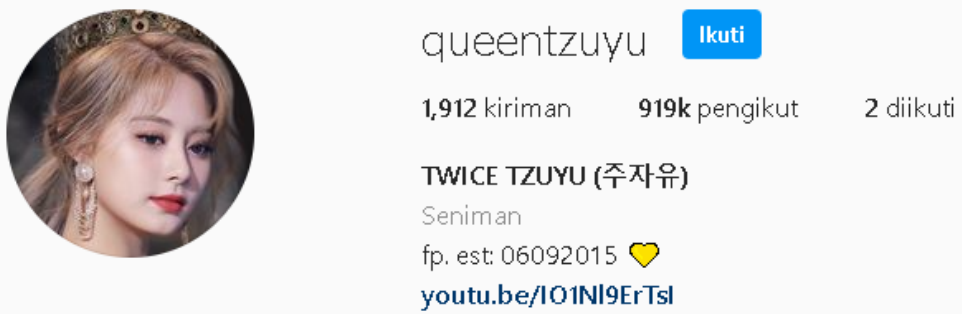

Gambar 3. Akun Instagram queentzuyu

Sumber : https://www.instagram.com/queentzuyu/?hl=id (diakses pada 20-10-2021)

\section{d. ivaanalawi}
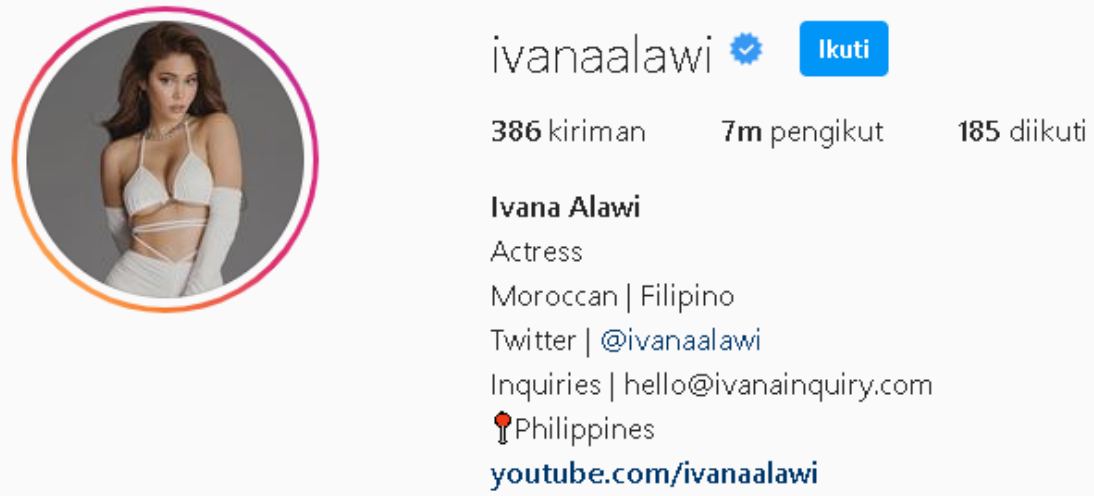

Gambar 4. Akun Instagram ivaanalawi

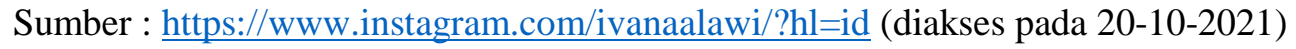

\section{e. bingbing_fan}
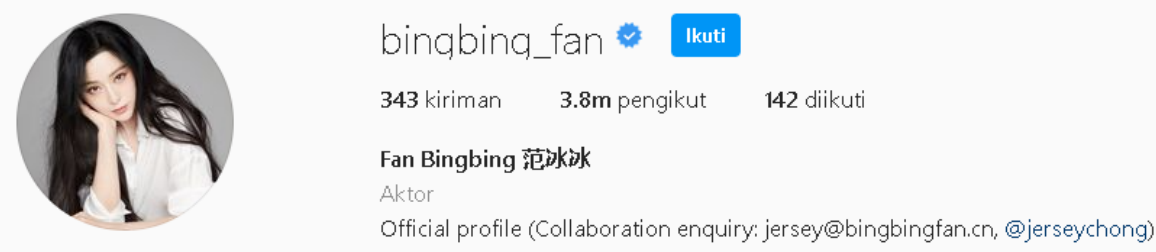
Gambar 5. Akun Instagram bingbing_fan

Sumber : https://www.instagram.com/bingbing_fan/?hl=id (diakses pada 20-10-2021)

\section{f. aishwaryaraibachchan_arb}
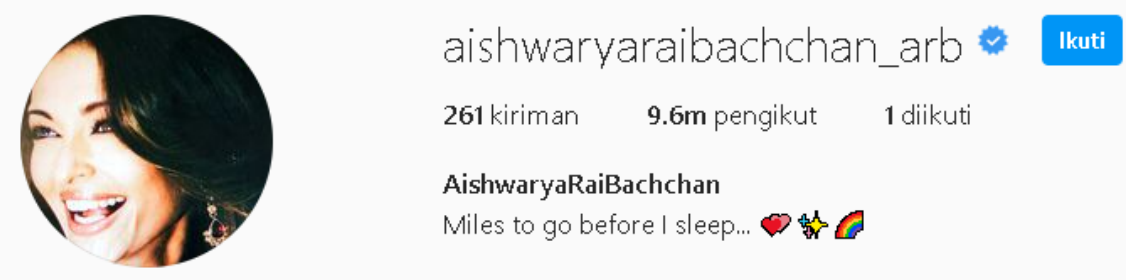

Gambar 6. Akun Instagram aishwaryaraibachchan_arb

Sumber : https://www.instagram.com/aishwaryaraibachchan arb/?hl=id (diakses pada 20-10-2021)

\section{g. julianaevans}

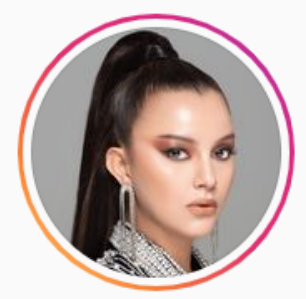

\section{julianaevans $*$ Ikuti}

4,528 kiriman 1m pengikut 1,320 diikuti
Juliana Sophie Evans
Tokoh Publik
Founder @jevansjewelry
Ambassador Tourism Selangor @discoverselangor
jevans.my/shopee

Gambar 7. Akun Instagram Julianaevans

Sumber : https://www.instagram.com/julianaevans/?hl=id (diakses pada 20-10-2021)

\section{h. natashawilona12}
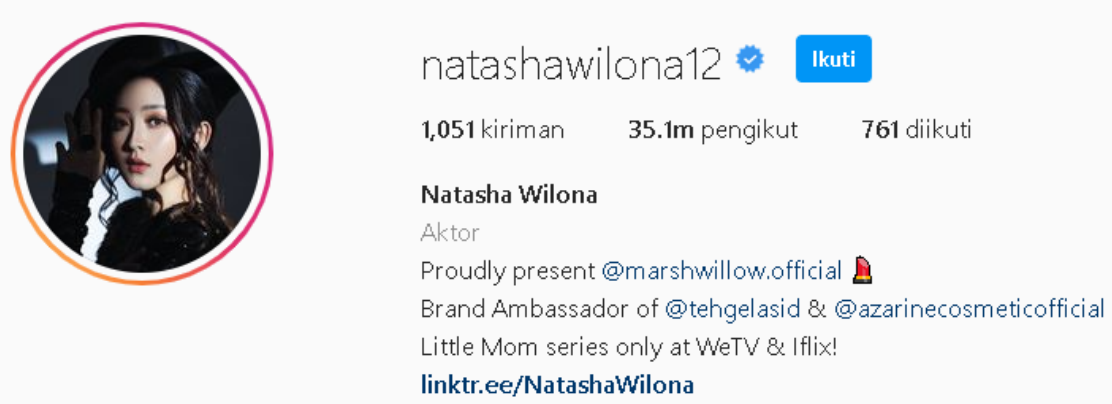
Gambar 8. Akun Instagram natashawilona12

Sumber :

https://www.instagram.com/natashawilona12/?hl=id\#: :text=Natasha\%20Wilona\%20(\%40natashawilona 12)\%20\%E2\%80\%A2\%20Instagram\%20photos\%20and\%20videos (diakses pada 20-10-2021)

\section{i. rern_nat}
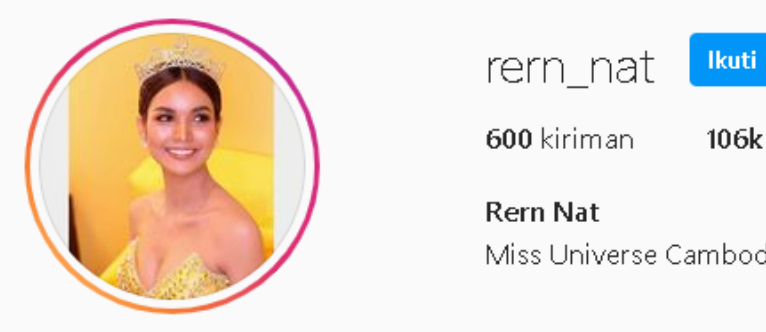

Gambar 9. Akun Instagram rern_nat

Sumber : https://www.instagram.com/rern nat/?hl=id (diakses pada 20-10-2021)

\section{j. diemmyvu}
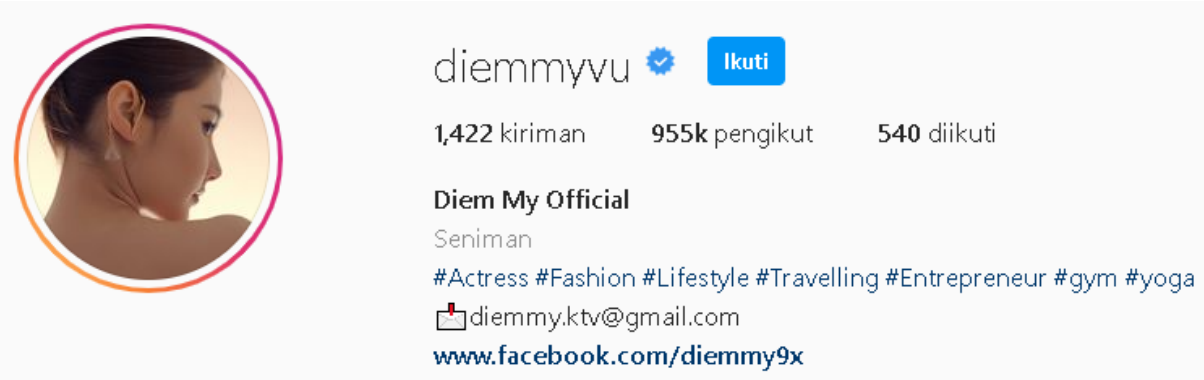

Gambar 10. Akun Instagram deimmyvu

Sumber : https://www.instagram.com/diemmyvu/ (diakses pada 20-10-2021)

Dari kesepuluh akun Instagram 10 Daftar Wanita Tercantik Di Asia, peneliti menemukan nilai dari masingmasing variabel yang ada untuk menghitung rasio Post to Followers dari setiap akun. Pada akun Instagram terdapat 8 variabel, diantaranya yaitu :

\section{Posts}



2. Followers
3. Following
4. Image Likes
5. Image Comments
6. Video Views
7. Video Likes
8. Video Comments

Dari kedelapan variabel tersebut peneliti hanya fokus untuk menemukan hasil dari 2 variabel, yaitu :

\section{Post \\ 2. Followers}

Dari kedua variabel tersebut kemudian dianalisa sehingga menemukan nilai rata-rata dari variabel post dan variable followers. Untuk menghitung nilai rata-rata dari variabel post dan variabel followers yaitu dengan cara mengambil minimal 10 postingan kemudian di hitung sehingga menemukan nilai rata-rata dari masingmasing variabel. Berikut merupakan tabel nilai rata-rata dari masing-masing Daftar Wanita Tercantik Di Asia, yaitu :

Tabel 1. Analisa Nilai Rata-Rata Nilai Variabel Post dan followers Akun Instagramyaelshelbia

\begin{tabular}{|c|c|c|c|c|}
\hline \multicolumn{2}{|c|}{ yaelshelbia } & \multicolumn{1}{c|}{} \\
\hline No & $\begin{array}{c}\text { Video } \\
\text { Likes }\end{array}$ & $\begin{array}{c}\text { Video } \\
\text { Comment }\end{array}$ & $\begin{array}{c}\text { Video } \\
\text { Share }\end{array}$ & $\begin{array}{c}\text { Video } \\
\text { Views }\end{array}$ \\
\hline 1 & 109899 & 860 & - & 298002 \\
\hline 2 & 20963 & 145 & - & 117313 \\
\hline 3 & 53307 & 380 & - & 151673 \\
\hline 4 & 43579 & 287 & - & 449219 \\
\hline 5 & 23971 & 202 & - & 319055 \\
\hline 6 & 91369 & 473 & - & 880631 \\
\hline 7 & 23939 & 140 & - & 104815 \\
\hline 8 & 25912 & 184 & - & 153777 \\
\hline 9 & 88240 & 960 & - & 480609 \\
\hline 10 & 108091 & 944 & - & 633499 \\
\hline Total & $\mathbf{5 8 9 2 7}$ & $\mathbf{4 5 7 , 5}$ & - & $\mathbf{3 5 8 8 5 9 , 3}$ \\
\hline
\end{tabular}

Sumber : Pengolah Data Excel

Tabel 2. Analisa Nilai Rata-Rata Nilai Variabel Post dan followers Akun Instagram lalalalisa_m

\begin{tabular}{|c|c|c|c|c|}
\hline \multicolumn{2}{|c|}{ lalalalisa_m } & \multicolumn{3}{|c|}{} \\
\hline No & Video Likes & $\begin{array}{c}\text { Video } \\
\text { Comment }\end{array}$ & $\begin{array}{c}\text { Video } \\
\text { Share }\end{array}$ & Video Views \\
\hline 1 & 4084150 & 35784 & - & 12333512 \\
\hline 2 & 6529164 & 195115 & - & 15238582 \\
\hline
\end{tabular}




\begin{tabular}{|c|c|c|c|c|}
\hline 3 & 5269196 & 116269 & - & 10321304 \\
\hline 4 & 5432033 & 126158 & - & 9784263 \\
\hline 5 & 5374401 & 182918 & - & 10830408 \\
\hline 6 & 4371988 & 109118 & - & 8343281 \\
\hline 7 & 6614143 & 56272 & - & 6614141 \\
\hline 8 & 3557192 & 68827 & - & 8757048 \\
\hline 9 & 5391911 & 127484 & - & 15715045 \\
\hline 10 & 8454795 & 57477 & - & 8454795 \\
\hline Total & $\mathbf{5 5 0 7 8 9 7 , 3}$ & $\mathbf{1 0 7 5 4 2 , 2}$ & - & $\mathbf{1 0 6 3 9 2 3 7 , 9}$ \\
\hline
\end{tabular}

Sumber : Pengolah Data Excel

Tabel 3. Analisa Nilai Rata-Rata Nilai Variabel Post dan followers Akun Instagram queentzuyu

\begin{tabular}{|c|c|c|c|c|}
\hline \multicolumn{2}{|c|}{ queentzuyu } & \multicolumn{1}{c|}{} \\
\cline { 1 - 2 } No & $\begin{array}{c}\text { Video } \\
\text { Likes }\end{array}$ & $\begin{array}{c}\text { Video } \\
\text { Comment }\end{array}$ & $\begin{array}{c}\text { Video } \\
\text { Share }\end{array}$ & $\begin{array}{c}\text { Video } \\
\text { Views }\end{array}$ \\
\hline 1 & 55719 & 261 & - & 188129 \\
\hline 2 & 22175 & 73 & - & 95774 \\
\hline 3 & 28265 & 102 & - & 111731 \\
\hline 4 & 30237 & 143 & - & 84062 \\
\hline 5 & 60162 & 417 & - & 174277 \\
\hline 6 & 27389 & 99 & - & 98417 \\
\hline 7 & 38976 & 222 & - & 231354 \\
\hline 8 & 32974 & 209 & - & 153644 \\
\hline 9 & 27982 & 116 & - & 114200 \\
\hline 10 & 27335 & 106 & - & 134669 \\
\hline Total & $\mathbf{3 5 1 2 1 , 4}$ & $\mathbf{1 7 4 , 8}$ & - & $\mathbf{1 3 8 6 2 5 , 7}$ \\
\hline \multicolumn{5}{|c|}{ Sumber : Pengolah Data Excel } \\
\hline
\end{tabular}

Tabel 4. Analisa Nilai Rata-Rata Nilai Variabel Post dan followers Akun Instagram ivanaalawi

\begin{tabular}{|c|c|c|c|c|}
\hline \multicolumn{2}{|c|}{ ivanaalawi } & \multicolumn{1}{c|}{} \\
\cline { 1 - 2 } No & $\begin{array}{c}\text { Video } \\
\text { Likes }\end{array}$ & $\begin{array}{c}\text { Video } \\
\text { Comment }\end{array}$ & $\begin{array}{c}\text { Video } \\
\text { Share }\end{array}$ & Video Views \\
\hline 1 & 190731 & 852 & - & 2795397 \\
\hline 2 & 402355 & 3172 & - & 2676757 \\
\hline 3 & 163044 & 4017 & - & 2305838 \\
\hline 4 & 59020 & 1088 & - & 684599 \\
\hline 5 & & & - & \\
\hline
\end{tabular}




\begin{tabular}{|c|c|c|c|c|}
\hline 6 & & & - & \\
\hline 7 & & & - & \\
\hline 8 & & & - & \\
\hline 9 & & & - & \\
\hline 10 & & & - & \\
\hline Total & $\mathbf{2 0 3 7 8 7 , 5}$ & $\mathbf{2 2 8 2 , 2 5}$ & - & $\mathbf{2 1 1 5 6 4 7 , 7 5}$ \\
\hline
\end{tabular}

Sumber : Pengolah Data Excel

Tabel 5. Analisa Nilai Rata-Rata Nilai Variabel Post dan followers Akun Instagram bingbing_fan

\begin{tabular}{|c|c|c|c|c|}
\hline \multicolumn{2}{|c|}{ bingbing_fan } & \multicolumn{1}{c|}{$\begin{array}{c}\text { Video } \\
\text { Views }\end{array}$} \\
\hline 1 & 11012 & 236 & - & 57305 \\
\hline 2 & 13020 & 124 & - & 114092 \\
\hline 3 & 18274 & 414 & - & 139629 \\
\hline 4 & 62101 & 1124 & - & 511364 \\
\hline 5 & 11084 & 153 & - & 82548 \\
\hline 6 & 42657 & 1130 & - & 446674 \\
\hline 7 & 29863 & 503 & - & 185851 \\
\hline 8 & 37509 & 1113 & - & 367812 \\
\hline 9 & 84731 & 630 & - & 836954 \\
\hline 10 & 69602 & 829 & - & 403693 \\
\hline Total & $\mathbf{3 7 9 8 5 , 3}$ & $\mathbf{6 2 5 , 6}$ & - & $\mathbf{3 1 4 5 9 2 , 2}$ \\
\hline
\end{tabular}

Tabel 6. Analisa Nilai Rata-Rata Nilai Variabel Post dan followers Akun Instagram aishwaryaraibachchan_arb

\begin{tabular}{|c|c|c|c|c|}
\hline \multicolumn{3}{|c|}{ aishwaryaraibachchan_arb } & \multicolumn{1}{l}{} \\
\cline { 1 - 2 } No & $\begin{array}{c}\text { Video } \\
\text { Likes }\end{array}$ & $\begin{array}{c}\text { Video } \\
\text { Comment }\end{array}$ & $\begin{array}{c}\text { Video } \\
\text { Share }\end{array}$ & $\begin{array}{c}\text { Video } \\
\text { Views }\end{array}$ \\
\hline 1 & 243763 & 1548 & - & 2450241 \\
\hline 2 & 356449 & 2472 & - & 3257600 \\
\hline 3 & 446311 & 5218 & - & 3135474 \\
\hline 4 & 301481 & 2060 & - & 2241000 \\
\hline 5 & 449182 & 3191 & - & 3516256 \\
\hline 6 & 251360 & 1309 & - & 3458073 \\
\hline 7 & 94720 & 832 & - & 479551 \\
\hline
\end{tabular}




\begin{tabular}{|c|c|c|c|c|}
\hline 8 & 105532 & 947 & - & 711532 \\
\hline 9 & 155021 & 2225 & - & 1193732 \\
\hline 10 & 173340 & 1363 & - & 1637671 \\
\hline Total & $\mathbf{2 5 7 7 1 5 , 9}$ & $\mathbf{2 1 1 6 , 5}$ & - & $\mathbf{2 2 0 8 1 1 3}$ \\
\hline \multicolumn{5}{|c}{ Sumber : Pengolah Data Excel }
\end{tabular}

Tabel 7. Analisa Nilai Rata-Rata Nilai Variabel Post dan followers Akun Instagram julianaevans

\begin{tabular}{|c|c|c|c|c|}
\hline \multicolumn{2}{|c|}{ julianaevans } & \multicolumn{3}{c|}{} \\
\cline { 1 - 2 } No & Video Likes & $\begin{array}{c}\text { Video } \\
\text { Comment }\end{array}$ & $\begin{array}{c}\text { Video } \\
\text { Share }\end{array}$ & Video Views \\
\hline 1 & 1316 & 12 & - & 10713 \\
\hline 2 & 286 & & - & 2340 \\
\hline 3 & 3002 & 23 & - & 54750 \\
\hline 4 & 804 & 8 & - & 7698 \\
\hline 5 & 420 & 4 & - & 4443 \\
\hline 6 & 929 & 8 & - & \\
\hline 7 & 1745 & 11 & - & 27225 \\
\hline 8 & 2591 & 19 & - & 18698 \\
\hline 9 & 1275 & 13 & - & 218564 \\
\hline 10 & 12066 & 94 & - & $\mathbf{4 3 0 5 3 , 8 7 5}$ \\
\hline Total & $\mathbf{2 4 4 3 , 4}$ & $\mathbf{2 1 , 3 3 3 3 3 3 3 3}$ & - & \\
\hline
\end{tabular}

Sumber : Pengolah Data Excel

Tabel 8. Analisa Nilai Rata-Rata Nilai Variabel Post dan followers Akun Instagram natashawilona12

\begin{tabular}{|c|c|c|c|c|}
\hline \multicolumn{2}{|c|}{ natashawilona12 } & \multicolumn{5}{|c|}{$\begin{array}{c}\text { Video } \\
\text { No }\end{array}$} & $\begin{array}{c}\text { Video } \\
\text { Likes }\end{array}$ & $\begin{array}{c}\text { Video } \\
\text { Comment }\end{array}$ & $\begin{array}{c}\text { Video } \\
\text { Share }\end{array}$ & $\begin{array}{c}\text { Views } \\
\text { Comnnn}\end{array}$ & 137000 & 1350 & - & \\
\hline 2 & 141641 & 1610 & - & 995277 \\
\hline 3 & 143279 & 1083 & - & 1011292 \\
\hline 4 & 67118 & 585 & - & 416433 \\
\hline 5 & 497000 & 3058 & - & \\
\hline 6 & 93899 & 1627 & - & 691378 \\
\hline 7 & 100919 & 1465 & - & 646002 \\
\hline 8 & 128996 & 1932 & - & 733344 \\
\hline 9 & 115739 & 2088 & - & 753923 \\
\hline 10 & 129745 & 2158 & - & 708772 \\
\hline
\end{tabular}




\section{\begin{tabular}{l|l|l|l|l|} 
Total & 155533,6 & 1695,6 & - & 744552,625 \\
\hline
\end{tabular}}

Sumber : Pengolah Data Excel

Tabel 9. Analisa Nilai Rata-Rata Nilai Variabel Post dan followers Akun Instagram rern_nat

\begin{tabular}{|c|c|c|c|c|}
\hline \multicolumn{2}{|c|}{ rern_nat } & \multicolumn{5}{|c|}{} \\
\cline { 1 - 2 } No & $\begin{array}{c}\text { Video } \\
\text { Likes }\end{array}$ & $\begin{array}{c}\text { Video } \\
\text { Comment }\end{array}$ & $\begin{array}{c}\text { Video } \\
\text { Share }\end{array}$ & Video Views \\
\hline 1 & 4124 & 22 & - & 15642 \\
\hline 2 & 9322 & 68 & - & 40781 \\
\hline 3 & 7323 & 135 & - & 28889 \\
\hline 4 & & 6 & - & 9886 \\
\hline 5 & 2711 & 44 & - & 13780 \\
\hline 6 & 1361 & 6 & - & 13439 \\
\hline 7 & 987 & 13 & - & 6614 \\
\hline 8 & 4145 & 69 & - & 25460 \\
\hline 9 & 2389 & 25 & - & 17490 \\
\hline 10 & 2245 & 25 & - & 15805 \\
\hline Total & $\mathbf{3 8 4 5 , 2 2 2 2 2}$ & $\mathbf{4 1 , 3}$ & - & $\mathbf{1 8 7 7 8 , 6}$ \\
\hline
\end{tabular}

Sumber : Pengolah Data Excel

Tabel 10. Analisa Nilai Rata-Rata Nilai Variabel Post dan followers Akun Instagram diemmvyu

\begin{tabular}{|c|c|c|c|c|}
\hline \multicolumn{2}{|c|}{ diemmyvu } & \multicolumn{5}{|l|}{} \\
\cline { 1 - 2 } No & $\begin{array}{c}\text { Video } \\
\text { Likes }\end{array}$ & $\begin{array}{c}\text { Video } \\
\text { Comment }\end{array}$ & Video Share & Video Views \\
\hline 1 & 1726 & 25 & - & \\
\hline 2 & 1907 & 16 & - & \\
\hline 3 & 6795 & 99 & - & \\
\hline 4 & 4348 & 43 & - & 32693 \\
\hline 5 & 3617 & 31 & - & 35402 \\
\hline 6 & 6388 & 36 & - & 45232 \\
\hline 7 & 1970 & 13 & - & 15199 \\
\hline 8 & 1961 & 15 & - & 19072 \\
\hline 9 & 2076 & 22 & - & 28845 \\
\hline 10 & 2306 & 11 & - & 31497 \\
\hline Total & $\mathbf{3 3 0 9 , 4}$ & $\mathbf{3 1 , 1}$ & - & $\mathbf{2 9 7 0 5 , 7 1 4 2 9}$ \\
\hline
\end{tabular}

Sumber : Pengolah Data Excel 
Setelah menghitung nilai rata-rata tersebut, maka akan menemukan hasil akhir nilai rata-rata dari variabel post dan variable followers :

Tabel 11. Nilai Variabel Pada Akun Instagram 10 Daftar Wanita Tercantik Di Asia 2021

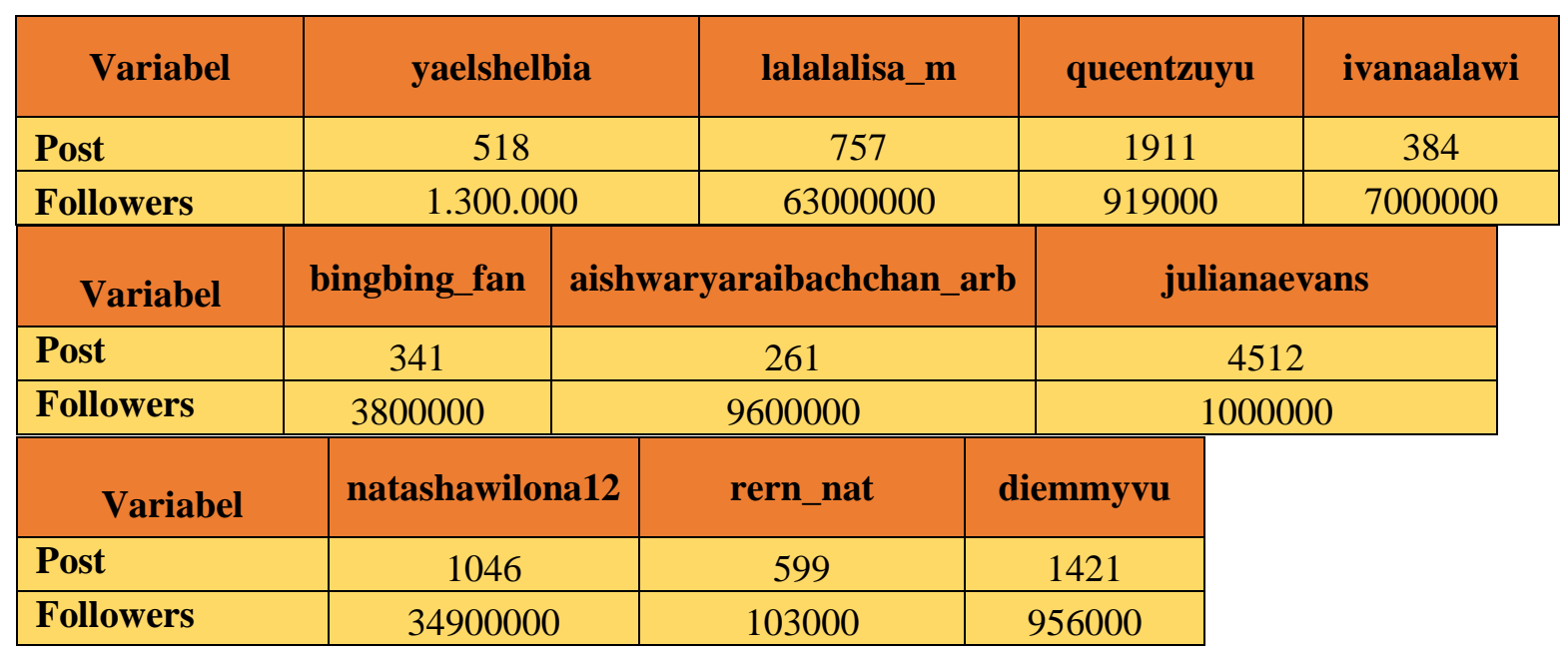

Sumber : Pengolah Data Excel

Pada umumnya Rasio merupakan perbandingan satu angka dengan angka lain yang membentuk suatu hubungan. Rasio merupakan suatu angka digambarkan dalam perbandingan suatu pola dengan pola lainnya serta dinyatakan dalam persentase. Instagram yang nantinya akan diformulasikan menjadi rasio - rasio harus memenuhi syarat -syarat teknis pada settingan Instagram untuk dapat dianalisa yaitu : Merupakan akun dengan status publik atau bukan privat sehingga data dapat diakses tanpa harus meminta ijin dari pemilik akun. Kolom komentar tidak di non aktifkan (disable) sehingga kolom komentar mendefinisikan sebuah angka yang menunjukan jumlah komentar pada sebuah postingan. Dalam menentukan sebuah rasio dibutuhkan minimal 2 variabel yang dibandingkan sehingga menghasilkan sebuah nilai yang hasil akhirnya dinyatakan dalam persentase. Dari seluruh variable yang ditemukan akan dibandingkan dengan seluruh variabel yang di temukan lalu diuji relevansi nya sehingga dapat ditentukan apakah perbandingan antara kedua variabel dapat dikatagorikan sebagai rasio. Namun pada penelitian kali ini hanya berfokus untuk menghitung Post to Followers Ratio. Untuk menghitung kredibilitas dari masing-masing akun Instagram, peneliti menghitung dengan cara variabel 1 akan dibagi dengan variabel 2, sehingga ditemukan hasil analisisa dari rasio tersebut.

Tabel 12. Hasil Perhitungan Rasio Akun Instagram

\begin{tabular}{|c|l|c|c|c|c|}
\hline No & \multicolumn{1}{|c|}{ Ratio } & yaelshelbia & lalalalisa_m & queentzuyu & ivanaalawi \\
\hline \multirow{1}{*}{1} & $\begin{array}{l}\text { Post to Followers } \\
\text { Ratio }\end{array}$ & 0,000398462 & $1,20159 \mathrm{E}-05$ & 0,002079434 & $5,48571 \mathrm{E}-05$ \\
\hline
\end{tabular}




\begin{tabular}{|c|c|c|c|}
\hline \multicolumn{2}{|l|}{$8.97368 \mathrm{E}-05$} & $2.71875 \mathrm{E}-05$ & 0,004512 \\
\hline natashawilona12 & rern_nat & diemmyvu & \\
\hline $2,99713 \mathrm{E}-05$ & 0,005815534 & 0,001486402 & \\
\hline
\end{tabular}

Sumber : Pengolah Data Excel

Post to Followers Ratio memiliki karakteristik yang rendah, artinya semakin rendah nilai yang dihasilkan maka semakin baik kredibilitas dari performa akun tersebut. Untuk memberikan peringkat pada masingmasing Wanita Tercantik Di Asia 2021, peneliti memberikan angka 10 kepada vendor yang mendapatkan nilai tertinggi dan angka 1 untuk Wanita Tercantik Di Asia 2021 yang mendapatkan nilai terendah. Berikut merupakan tabel urutan nilai yang dihasilkan oleh Wanita Tercantik Di Asia 2021

Tabel 13. Nilai Rasio Akun Instagram dari 10 Daftar Wanita Tercantik Di Asia 2021

\begin{tabular}{|c|c|c|c|c|}
\hline yaelshelbia & Lalalalisa_m & queentzuyu & ivanaalawi & bingbing_fan \\
\hline 3 & 6 & 4 & 9 & 10 \\
\hline aishwaryaraibachchan_arb & julianaevans & natashawilona12 & rern_nat & diemmyvu \\
\hline 7 & 1 & 8 & 5 & 2 \\
\hline
\end{tabular}

Sumber : Pengolah Data Excel

Dari Tabel Nilai Rasio Akun Instagram 10 Daftar Wanita Tercantik Di Asia 2021 dapat simpulkan bahwa bingbing_fan mendapatkan nilai tertinggi untuk rasio Post to Followers. Sedangkan akun Instagram julianaevans mendapatkan nilai terendah untuk rasio ini. Jadi, pada penelitian ini bingbing_fan memiliki kredibilitas performa yang lebih baik dibandingkan dengan akun isntagram yang lainnya.

\section{KESIMPULAN}

Tujuan dari penelitian ini adalah mengetahui kredibilitas performa dari akun Instagram 10 Daftar Wanita Tercantik Di Asia 2021 menggunakan Post to Foloowers Ratio. 10 Daftar Wanita Tercantik Di Asia 2021 tersebut diantaranya : yaelshelbia, lalalalisa_m, queentzuyu, ivanaalawi, bingbing_fan, aishwaryaraibachchan_arb, julianaevans, natashawilona12, rern_nat, diemmyvu. Dari kesepuluh Daftar Wanita Tercantik Di Asia 2021 tersebut dapat disimpulkan bahwa :

1. Peringkat pertama diraih oleh bingbing_fan dengan nilai tertinggi yaitu $8,97368 \mathrm{E}-05$

2. Peringkat kedua diraih oleh ivanaalawi dengan nilai 5,48571E-05

3. Peringkat ketiga diraih oleh natashawilona12 dengan nilai 2,99713E-05

4. Peringkat keempat diraih oleh aishwaryaraibachchan_arb dengan nilai 2,71875E-05

5. Peringkat kelima diraih oleh rern_nat dengan nilai 0,005815534

6. Peringkat keenam diraih oleh lalalalisa_m dengan nilai 1,20159E-05 
7. Peringkat ketujuh diraih oleh queen tzuyu dengan nilai 0,002079434

8. Peringkat kedelapan diraih oleh yaelshelbia dengan nilai 0,000398462

9. Peringkat kesembilan diraih oleh diemmyvu dengan nilai 0,001486402

10. Peringkat kelima diraih oleh julianaevans dengan nilai terendah yaitu 0,004512

\section{DAFTAR PUSTAKA}

ANWAR SIDIQ. 2017. "PEMANFAATAN INSTAGRAM SEBAGAI MEDIA DAKWAH ( Study Akun @fuadbakh ).” Skripsi 110 (9): 1689-99. http://repository.radenintan.ac.id/2201/3/BAB_II.pdf.

Asfihan, Akbar. 2021. "Instagram Adalah : Sejarah, Fungsi \& Keistimewaan Instagram.” 2021. https://adalah.co.id/instagram/.

dianisa. 2020. "Pengertian Instagram | Sejarah, Fungsi, Tujuan Hingga Manfaat Saat Ini." https://dianisa.com/pengertian-instagram/.

Dosen Pendidikan 2, .com. 2021. "Variabel Adalah - Pengertian Menurut Para Ahli, Macam, Contoh." 2021. https://www.dosenpendidikan.co.id/variabel-adalah/.

Hendika Permana, I Putu. 2021. "View of Analisis Rasio Pada Instagram Untuk Penelitian Kualitatif Menggunakan Metode Ekploratif."

https://www.infoteks.org/journals/index.php/jsikti/article/view/109/154.

“Instagram - Wikipedia Bahasa Indonesia, Ensiklopedia Bebas.” n.d. Accessed November 3, 2021. https://id.wikipedia.org/wiki/Instagram.

J Muntu, Steeve A, Joanne M Pingkan Tangkudung, and Leviane J H Lotulung. 2021. "STUDI NETNOGRAFI PADA MEDIA SOSIAL INSTAGRAM.” ACTA DIURNA KOMUNIKASI 3 (4). https://ejournal.unsrat.ac.id/index.php/actadiurnakomunikasi/article/view/36005.

Untari, Dewi, and Dewi Endah Fajariana. 2018. "Strategi Pemasaran Melalui Media Sosial Instagram (Studi Deskriptif Pada Akun @ Subur_Batik).” Widya Cipta: Jurnal Sekretari Dan Manajemen 2 (2): 271-78. https://doi.org/10.31294/WIDYACIPTA.V2I2.4387.G2658.

Winarso, Bambang. 2015. “Apa Itu Instagram, Fitur Dan Cara Menggunakannya?| Dailysocial.” https://dailysocial.id/post/apa-itu-instagram. 